\title{
A BAREFOOT SAILOR BECOMES AN IOWA FARMER: \\ Samuel Clough, 1824-1905
}

submitted by Mrs. E. B. Troxell

Tingley, lowa

The following article was written by Samuel Clough, already a septuagenarian, between the years of 1898 and 1901. The original manuscript is in the possession of his greatgranddaughter, Mrs. Earl Kessler of Afton, Iowa.

Original puctuation, spelling and grammatical construction have been retained.

At home, Union Co. Iowa Post Office, Ellston, Iowa

December 19, 1898

I, Samuel Clough, sit down at the age of 74 to write a few past incidents and memoirs of my life, works, and travels.

My fathers name was Samuel, his fathers name was Jobe Clough. My mothers name was Hannah Clough, her fathers name was John Philbrick.

I was born April 26, 1824 on the farm my father was born on, in the town of Alma, Lincoln Co., State of Maine.

After I was of school age I went to school in summer time for a few weeks until I was 9 years old, when I quit summer school and went to winter school about 2 months in the year until I was 19 years old. When I was 9 years old I began to plow on my fathers farm. I could hold the plow and drive oven. From then on my principal education consisted in learning how to work the little farm until December 1 before I was 20 years old. December 8, 1843, when I shipped on board the ship Ontario. Captain Bearstow from Wiscassett to New Orleans, as a green hand before the mast for 8 dollars per month. 
Out of that I paid 20 cents per month tax support the Marine Hospital leaving savings of $\$ 7.80$ as wages. The ship arrived in New Orleans about the third of January 1814 after a rather pleasant trip. The ship laid there idle until the next summer, as I understood afterward. I stayed with the ship until about the 20th of April. I had received one month pay in advance to fit me with some clothing which I needed, but I got but little money after that. When I left the ship there were some 20 dollars due me, but I could get none and I had no shoes, and I owed one dollar to a man who a few weeks before had loaned me a dollar to pull a bad tooth with which I had suffered with for several weeks.

It had been getting rather dull staying in New Orleans and warm weather coming on and I wanted to be learning Seamanship, so I thought I would find another ship and go to sea again. Freighters were low, times on the sailors were rather hard, wages were low. The only chance I could find was to go to Liverpool in England in the ship Laura. Captain Show of Bucksport, Maine, for $\$ 7.80$ a month, and had to agree to go without any pay in advance. Now I was going to Liverpool, had no shoes was owing a friend a dollar, but had not so much as one red cent. I had been bare foot for two months, but it was not very cold in that latitude even in February and March but I expected to get up North where I might see ice burgs in April. I expected to get money of Captain Bearstow until within six hours of the time appointed for the ship Laura to sail. I worked on the ship Laura three days before she was to sail in the evening, about two hours before she was to sail I went to the Captain and told him I wanted one dollar, and if he would let me have two dollars I would be very glad. He put his hand in his pocket and pulled out one dollar and fifty cents and says here take that in such a gruff tone that I dare not say more. So I took it and marched off. I could not pay the dollar and buy the shoes with that, so I decided to go and pay the dollar and went to Europe totally barefoot for want of a dollar to buy a pair of shoes.

It was pretty cold part of the way across the Atlantic Ocean, but I lived through it and quite nicely. That is the 
last time I was out of money. When I got to Liverpool the first thing I bought was a good pair of English shoes made to order. They done me more service than any other shoes I ever had. They cost me $\$ 2.50$. The ship carried cotton and was 43 days on the passage. I remained with the ship until she discharged her cargo of cotton and took a general cargo for Boston, Massachusetts, where she arrived about September 12 as near as I remember.

September 19, 1844, I began to work for the Boston and Maine Railroad Company for Seven and six-pence a day, $\$ 1.25$, and took board of Clark Durgan on the corner of Canall and Causway Street at $\$ 2.50$ per week. I continued to work for the R. R. Company until about the first of January, 1845.

Sometime in January, 1845 say about the 10 I went out to the pond and worked for Luther Wieth, some six miles from Boston, cutting ice for $\$ 1.00$ per day at first, but soon he advanced my wages to $\$ 1.50$ and gave me charge of part of the work. I worked there during the ice season until about the middle of March when I went into Boston. While cutting ice I boarded with a shoemaker and farmer in the neighborhood whose daughter kept house for him.

About the first of April 1845 I began to work for Jeremiah Wetherby and Company to learn to cut stone in Boston, Massachusetts. I worked the first three months for my board that is they paid the price of my board $\$ 2.75$ per week, at Mr. Burgans. The next three months they paid me $\$ 10.00$ a month and board, that completed my apprenticeship. From that on until I took this Variloid, they paid me $\$ 1.42$ per day and I paid my own board. The smallpox got into my boarding house from which I took the Veriloid and was sick about a week. When I got well I went to Methuen and began to work February 13, 1846, to cut stone for John A. Carpenter and Company to build a dam across the Merimac River at Methuen to make water power for manufacturing purposes. I cut some of the first stone put in the dam. I got $\$ 1.50$ per day all winter, the highest wages paid for cutting stone for the winter.

The stone was quarried and cut in Pellham, New Hampshire, about 7 miles from where the dam was built. The stone 
was drawn with oxen and horses on wagons. Some sleds were used in the winter. Since that time a very large city has been built called Lawrence.

About April 3, 1847, I went back to Boston and the 9 of April went to work for Wetherby again for $\$ 1.75$ per day to cut stone. Sometime after this Wetherbys got a portion of the stone work for the Reservoir on Beacon Hill in Boston. $\mathrm{He}$ wanted me to go to Cape Ann where the stones was quarried and some of them were cut for his custom in Boston and other towns around, for they done a large business in stone work. They were to pay me $\$ 2.00$ per day to go to the Cape to cut stone for the Reservoir, and when I got there, Mr. Clifford the foreman and partner thought I could not earn 2 dollars a day as I was only an Apprentice the season before and said he would give me 4 cents per foot and up special measure for cutting bed and build work as it is called. So as by this time I had found out that I was no slouch of a stone cutter. I concluded to take it and went to work, and in about 3 weeks he found out I was making $\$ 3.00$ a day. Then he wanted me to cut some Cornist stone for a depot. Said he would give $\$ 1.75$ per foot in length so I cut cornist along side of his old friend.

Flood an old hand, who had worked for the firm several years and was counted an extra hand and was working for 3 dollars a day. Messers Clifford and Flood watched me pretty close until they found I was making $\$ 5.00$ per day. Flood was mad and Clifford went back on the price and that knocked me out of a job for I would not work for them any more. I demanded a settlement picked up my tools and went to Leadbeaters Island in Penobscot Bay in the State of Maine, and worked for Mr. (I have forgotten the name) who was getting out stone to go to Key West in the Gulf of Mexico for a port. I cut by the port and made $\$ 3.00$ a day until fall. About November 1, 1847 the Brigg Lucy Wotts, Captain Watly of St. George Maine come to the Island to load with stone for Tay Webb and she wanted a man to go as a sailor. I shiped and went to Key West thence to New Orleans was 33 days on the passage and received $\$ 17.95$ including unloading at Key West. December 16, 1846 Took board at Mrs. Smith's 
at $\$ 3.50$ per week. The 17 began to work for Clark Day and Stoupper for $\$ 1.25$ per day. They kept a large store of Hardware consisting of iron, tin, lead, farm implements, mechanical tools, oils, boat mill stones, grindstone portable mills, etc. January 8, 1847 began to board with A. Ruth on Jefferson St. New Orleans at $\$ 12.00$ per month February 14 began to board at Mrs. Hogdens Poidras Street for $\$ 3.00$ per week. Sold to Mr. Beain of Buffalo, New York, a pair of calfskin boots for $\$ 3.50$ he paid me $\$ 2.00$ and that was all I got. He soon went to Buffalo, New York. About April 10, 1847 began to board with Mrs. Verrieges, Phillips St. New Orleans at $\$ 3.50$ per week. I worked for Clark Day, Stamper and Co. until January 1 when I had $\$ 10.00$ per month the first of November 1857 , then $\$ 50.00$ per month and I was to have $\$ 50.00$ a month until January 1,1848 . Then I was to have such wages as they paid their other help which was then about $\$ 75.00$ per month. But in the Spring of 1847 my father died and it seemed necessary that I should go home to take care of the little farm and my mother, who lived on it at the time. Perhaps I should say here that my fathers farm and home sold under mortgage after I went to sea, and the next spring while I was in Boston learning to cut stone Elbridge Peasley a neighbor of ours in Alma Maine was up to Boston and he called on me and said that fathers farm was sold and nearly past redemption and that if I could redeem it, it would help them. I was a little past 21 years of age but had no money. But my sister Eliza had been working in Boston a number of years making boots and had 4 or 500 dollars in the Savings Bank, she said she would loan me some money if I could use it to save the place. So I went home and found I could buy the home part of the farm containing the buildings, and the best part of the land by paying $\$ 100$ dollars down and the ballance of the debt against it in a year or so. I went back to Boston, borrowed $\$ 100$ of Eliza and back to Maine and made the agreements and saved the place, and soon after I finished my trade and I began to earn money and paid all the debts off. My father lived on it while he lived, and Mother used it as long as she wanted it free of rent and after that I sold it to Brother Albert. 
Sometime in April 1847 Massers Clark Day Stampper and Co. allowed me to go home and paid me up according to our contract so far and kindly sent their team to take my chest and baggage to the ship without charge. When I left for Boston. To save traveling expenses I looked for and found a ship loading for Boston. I said to the Captain that I wanted to go to Boston with him. I would like to work my passage. He said I might go, so I went on board and turned to the same as any sailor and did not expect any wages. But when the Captain paid off his men he paid me as much as any of them, which was $\$ 14.00$ per month. We were just one month on board. From Boston I went to Maine where I arrived about the first of June as near as I remember.

My brother Albert had planted some corn and some potatoes, and he had gone to Gardiner to learn the carpenter trade and so I hoed the corn and potatoes and cut the hay and shingled the house and made some other repairs and provided for Mother harvested the corn and potatoes for her and left her what hay she wanted for her little stock, and employed Uncle Daniel Clough to bale some of the hay and sell it and rented him the hay ground for the next year and in the fall I went to New Orleans again by way of Boston, Albany, Buffalo, Landusky, Cincinnata, Memphis and on down the Mississippi River. Arrived in New Orleans. Found work in a Whole Sale and Real Estate Drug Store. Soon after the Cholera broke out in New Orleans. I was boarding at Mrs. Smiths and my room mate died with the cholera in about 2 hours after he was taken sick. In a few weeks after that I left New Orleans and come up the Mississippi and Ohio Rivers to Cincinnatti by steam boat on the way up there were 8 deaths on board the boat by cholera and one death by drowning before we reached the mouth of the Ohio River. I think that was in the beginning of the year of 1849. The great cholera year. I was sick in New Orleans with the symptoms of cholera and thought it best to leave there. I did not find employment in Cincinnata so I went North to Landusky City. By this time I had got nearly out of money and was obliged to hunt work. I soon fell into cutting ice for Mr. Roosevelt who had just received a lot of tools for cutting ice of Mr. Wyeth 
of Mass. whom I had worked for cutting ice on fresh pond 6 miles back of Boston a few years before. Mr. Roosevelt had never used those tools before and needed some expert help to cut his ice. I had used the tools and he was glad to have my help and I was glad to get the job. I worked at cutting ice and cribbing until I got money to go to Cleavel and Ohio by stage. I was intending to make my way back to Boston with a view of working at my trade cutting stone again. At Cleveland I found work with the Cleaveland, Columbus and Cincinnatti Railroad Co. who had began to build their R. R. the fall before. I got $\$ 25.00$ a month helping the Engineers to stake out the line and set grade stakes. I worked there until navagation opened when I took the first boat to Buffalo, New York and thence to Albany by rail. When at Albany I thought I would like to see New York City as I had never been there so I took one of Vanderbilts fine Steamers and run down to New York. The passage cost only $12 \frac{1}{2}$ cents or a york shilling as it was called in those days. The United States had began to build a dry dock and engine house of Maine granite in the Navy yard in Brooklin. I applied for work at a stone cutter. They put me to work on trial week and then gave me work at $\$ 2.00$ per day of 10 hours and I worked all summer. This was in 1849. I had a very pleasant time that summer good wages, nice job in a nice city, good boarding house with Mr. William Bovis and family, corner of Hudson Ave. and High street. They were a pleasant family to board with. The dry dock was a very nice job of fine cut granite and so was the Engine house. There were at one time in the summer when there was near 200 stone cutters at work, and there was a rule that if a man made a mistake in cutting a stone he would be suspended from work for a day or more. I was one of the very few who was not suspended during the seven months I worked there. I was one of the last four stone cutters that was discharged when cold weather come on and the work was stopped for the winter.

While in Brooklin I bought unseen 600 acres of land in Tennessee. December 17, 1849 I started to go and see it. I took maps and charts to sell on the way. I took the cars from New York to Reeding Penn. There I began to sell maps and travel 
on foot in the direction of Cumberland, Md. Thomas Jones a stone cutter went with me as far as Cumberland. We bought maps and charts published by Ensign and Thayer, No. 50 Ann Street, New York. I took $\$ 25.25$ worth about what I could carry and sold them before I got to Cumberland. I made about $\$ 1.00$ a day and expenses. Thomas Jones got tired and went back to New York. At Cumberland I fell in with an Englishman and his son. We then footed it over the Allegania Mts. to Brownsville on the Monangahela River, where we took deck passage on boat down the Monongahala and the Ohio rivers to the mouth of the Cumberland river where my English fellow travelers and I parted company. They went on to St. Louis and I took another boat and went up the Cumberland River to Nashville Tennessee. Here I stopped to see if the land I had bought had been recorded. I found the lands had been deeded by the State to parties who had sold them in New York and deeds recorded all right, so I pushed West on foot some 60 miles to the East bank of the Tennessee River where my land was supposed to lay. My journey West from Nashville was through a very sparcely settled country for more than $2 / 3$ of the way and many streams to ford. One stream was nearly up to my neck. I took off my clothes and tied them into a bundle and tied them to my valice and held them on my head and waded across. On arriving in the district where my land should have been and on inquiring I found my purchase was a perfect swindle. It came about on this wise. When as the state had sold all the land on a certain District lying on the East side of the Tennessee River that would sell for a very small price it passed a law to grant to any one who would pay the expenses of entering and surveying the remnants of land not sold (and that was a very small part of the land district) it appeared that the then entry taken and the then County Surveyor worked up a plan to make partition entry takers book and in the surveyors book and got deeds for them from the State and they were recorded in the State Capital and the old Quaker of whom I bought in New York told me afterwards that 18,000 acres of those lands had been sold in New York in one winter and the citizens in Tennessee 
told me that large lots of those Tille had been sold in the large cities in Europe. Those petition entries were located largely on the East bank of the Tennessee River, where the land was supposed to be good. In 5,000 acre tracts along the bank of the river they were located eleven entrys deep on top of the other. I found this out by refering to the County surveyors book which I had access to 2 weeks when I was there. The former Entry taker had died and the county surveyor had left the county, who had done this work. In order to find where my 600 acres was located $\mathrm{I}$ had to begin according to the survey at a point just below. Forms Creek on the East bank of the Tennessee River. Well after finding out how easily and how badly I had been swindled I concluded to pocket the loss and go back to New York. So I sold most of my spare clothing, my valice to help pay expenses and lighten my load and walked back to Nashville. There was one stretch of woods and hills and valleys, 12 miles between houses on the way. I am writing this from memory mostly. It is Feb. 1, 1900 and the things I am writing about today happened in the winter of 1849 and 1850 according to an occasional date furnished by some old papers that I had kept. In 50 years I find I have forgotten many things, places, and names which I would like to recall. There are some things that may seem trifling to others that I will put in here because my life has been made up of little lessons and I will relate one of them here. When I got back to Nashville, I was having a very bad cold and sore mouth, my mouth was so sore I could not eat much for several days and I think it was caused in this way. When my English comrad, before mentioned and I had taken deck passage on boat down the river from Brownsville we needed to provide our selves with something to eat on the way. We thought to join in buying provisions and cooking utensils and board together. They wanted to buy coffee pot and dishes, frying pan etc. I thought we had better buy cooked food and do without cooking. They couldn't see how to get along without coffee. I said we could live very well for 5 or 6 days on water I finally said I could do without any drink and I concluded to try the experiment so I lived on dry food, such as bread, cheese, smoked fish, etc. without a drop of fluid of any 
kind for 6 days and I felt no great inconvienience for the time for the want of drink, but I believe it was the cause of my sore mouth a week or two after I rested in Nashville about a week then took deck passage again down the Cumberland river and up the Ohio to Cincinnatta where I bought some maps and sold around Cincinnatta until I could order some maps and charts from New York, which I received in a few weeks. Then I went up the Ohio River to Bordersville in Virginia where I began to walk toward New York and sell maps on the way. I think it was in March 1850 I put in the following summer selling maps through Virginia, Maryland, Deleware, Penn., New York, New Jersey, and arrived in New York about the beginning of October following as near as I can remember. I sizzaged all the way on foot to within 50 miles of New York City. I struck on my way the Kanacoha River Charlestown the Hawks Nest, Greenbria Co. the Natural Bridge, Lexington, Stanton, Harrisburg, Wood Stock, Winchester, Charleston, Harpers Ferry, Lauden Company, Faerpox Co., Mt. Vernon in Virginia, Baltimore, Philadelphia, New York. A good way to find out how large a state is, is to walk over it. It was pretty hard work to sell maps on foot from house to house but I enjoyed the trip very much. I enjoyed the scenery of the country and I liked the people who were generally kind and hospitable. I made my journey and made fair wages and it was a good experience, although my land purchase and land hunt was a failure.

After getting back to New York I called on Arnold Buffern and Co., 11 Park Row, New York, I told him what I had found out about my Tenn. land and he paid me back $\$ 50.00$ of the $\$ 75.00$ which I paid down and we played quit. Having had success in selling maps I concluded continuing in the business and also concluded to invite my brother Albert to join me in Providence R. I. and we go South and sell. In the meantime I took out maps and went up the Hudson River to Vermont and across the state East by way of Mt. Tabor and Wood Stock to the New Hampshire line all on foot. Then I took the cars for Providence where I met Albert. Thence we went to New York and took out maps and went South into New 
Jersey and began to sell. After this our cousin Samuel Sevey came out and joined us in the business and we distributed maps, charts, and pictures through the country about Philadelphia, Baltimore, Washington, Northern Virginia, and Maryland. Sevey worked with us some 2 or 3 months then went back to Boston. Albert worked with me some 8 or 9 months and concluded to buy the little farm of me for which he paid me $\$ 400$ and he went back to Maine and went to farming. I continued map selling until the spring of 1852 when I concluded to go to Iowa by the way of Cumberland and Cincinnata, St. Louis and landed in Keokuk, Iowa, in June 1852. I walked from Keokuk to Fairfield where the United State land Office was. In the next winter I bought 240 acres adjoining my other land. I entered my first land in Henry Co. I think in July 1852. I then looked about the county and sold maps a few weeks, went up to Muscatine from there I went down the Mississippi River by steam boat to Burlington. By this time I had made up my mind to go to work on my land so I ordered a cart made to be used with oxen on the farm. I bought a sythe a rake and pitch fork and walked back to my land and carried my tools about 30 miles and began to mow some hay as I was intending to buy some young cattle which I did the next winter. I paid $\$ 6.00$ a head for some pretty good spring calves 11 head from Mr. George Ramsey, East of London. I bought other young cattle until I had about 36 head before spring and fed them on the hay I put up. I boarded with James Marting about 2 and $1 / 2$ miles North of my place. This was the nearest house to my place. Mr. Samuel Andrews lived the next nearest about 3 miles North Westerly. The nearest house on the East was Carson and the Jervises about 5 miles along the Virginia Grove. The nearest house South was Mr. Barters about 6 miles. The village of New London was nearly 11 miles South. Mt. Pleasant about 15 miles South West. Mr. Syp was the nearest neighbor in that direction about 10 miles from my place.

This was situated in a beautiful gentle rolling prairie no timber within 5 miles but about 200 acres on Crooked Creek about $1 \frac{1}{2}$ miles from where I built my first house, Virginia 
Grove on the North East 5 miles in sight. All else was prairie grass, thousands of tons of it. How I loved to mow it down, dry it and stack it.

There is a great many things and happenings pleasure and pains all along journeys through life I would like to write about but time will not permit and I will have to content myself with the mention of a very few. I have been very industrious and saving. I was determined to make a home and save some property and have a farm before I married. I have always enjoyed my labor what ever I done. When I went to sea, when I cut stone, when I cut ice, or sold maps or cut hay. I was happy and especially was I happy when I secured a thousand acres of as fine land nearly as I ever saw and had it paid for.

I regard labor as one of the greatest blessings that nature bestowed on man kind or any other creature. I have done a great deal of work. I have made 13 farms I have raised thousands of tons of feed and food for man and beast, such as grain, hay, beef, pork, fowels, vegetables, fruit, butter, eggs, honey to supply the wants of my fellow man. Labor has been no punishment to me for partaking of the fruit of knowledge work is pleasure, knowledge is power. Labor and knowledge enable us to make an honest living and be at rest when we die. Now in the fall of 1852 after putting up some hay and buildings a little house 14 feet square I went back to Maine and made a short visit. I went there by finishing my maps came back to Henry Co. Iowa bought a little more land and on the 17 day of April I married Mary F. Clough, Daughter of John and Grace Morley. We moved into our house and began to improve our house and began to improve our land as fast as we could, though it was a slow process when timber was scarce and 6 miles away and our principal market town was Burlington near 30 miles away and our team was made up of young wild steers. In $2 \frac{1}{2}$ years we got our timber stone and lumber and built a good substanial house 16 by $18 \mathrm{ft}$. and with a good cellar under it walled with rock and a chamber (small room above). Then we hauled the first house to within $10 \mathrm{ft}$. of the new one and built a room between 
them, then we had a house with 3 rooms, a cellar and chamber. Soon after this a portable circular saw mill came into the neighborhood of my 20 acres of timber in Virginia Grove about 6 miles from home and we went to work cutting logs and hauling them to mill and sawed out a frame for a barn 38 by 44 posts $16 \mathrm{ft}$. high and brought boards from Burlington and built a most substanial barn. I done nearly all the chopping, hauling, quarrying, and digging for those buildings with my own hands, with steers to haul. I also fenced ground fast as I could but it was 3 or 4 years before I raised much grain.

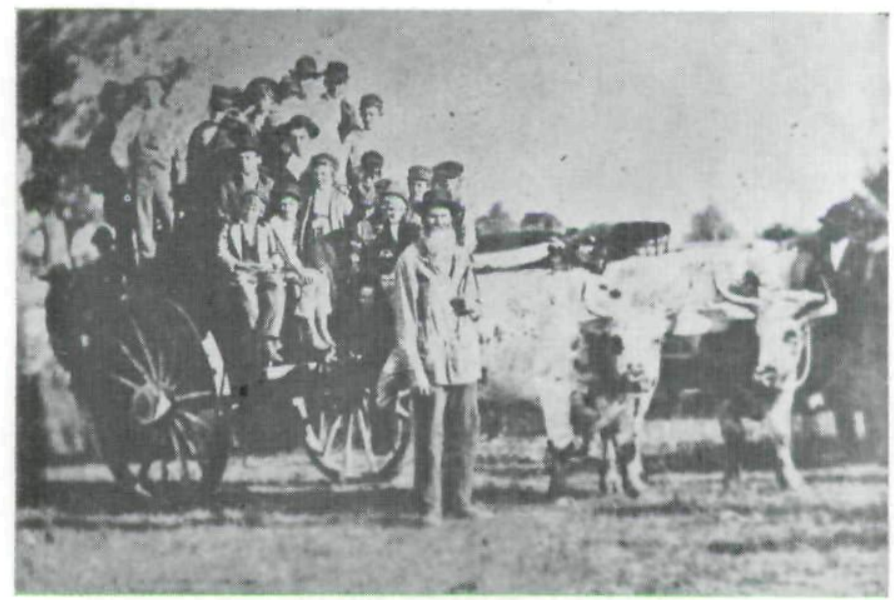

Samuel Clough and his 13 children

In the mean time I made good use of the prairie grass and hay. We continued to improve our land and farm and sell a piece of land once in a while for over 11 years when in the summer of $1864 \mathrm{I}$ sold the last $\frac{1 / 2}{2}$ section (320 a.) and my 20 acres of timber in Virginia Grove for $\$ 7500$. In the spring of 1863 I began to build a good substanial house 30 by 40 put a good cellar under all with rock wall and was plastering it when I sold so I finished the house and did not move into it. The sales of all the tract of land I had here amounted to $\$ 12,000$ including my improvements.

In September 1864 I made a sale of personal property and moved to Union County Iowa where I had previously 
bought of the United States 2 sections and one sixteenth of a section.

We arrived in Union Co. October 1, 1864. We brought 5 children with us to this county and moved into a spare house of Uncle Daniel Clough 5 miles from where we built our home where I now live. The county was very new and scarsely settled. No lumber to be had I went to work dug out rock in the bank of 12 mile creek for a cellar, before the ground froze and hauled them to our place ready to make a cellar in the spring, then to get lumber to build I logged on shares on Uncle John Cloughs land and hauled them to Kentreis and Shepards mill about $1 \frac{1}{2}$ miles away and gave $1 / 2$ the logs at the mill. During the winter and spring of that year I got the logs sawed and lumber hauled to my place and soon as the frost was out the ground, dug a cellar and laid up the wall and put the house during the summer and fall and moved in just a year after we arrived in the county. The house was 18 by 24 but substantially built. Shooted and shingled from the ground up all in one room, but not plastered. I filled the cracks with morter and it was quite comfortable. We lived in it about 6 years, by which time built another house 30 by $40 \mathrm{ft}$. put a cellar under all with rock wall. It will be noticed it took me a whole year to get our first house up including the breaking of about $30 \mathrm{a}$. of ground and putting up about 10 ton of hay and tending my family. Everything was wide apart from where I built to the timber, and mill was about 6 miles. From the mill to my farm it was 5 miles from where I lived to the quarry then on to my farm was 4 miles. So to complete the circle was about 18 miles more or less and to this I had to cross 5 streams that was unfortable often and in crossing 12 mile creek at one time I got the best horse I ever owned drowned. I paid $15 \phi$ a $\mathrm{lb}$. for nails to build my first stone house in this county. I paid $\$ 8.00$ a barrel for salt, $\$ 6.00$ a 100 for flour and went to Winterset in Madison Co. for it. I paid $\$ 1.00$ a bu. for corn and $50 \phi$ a dozen for sheaf oats of Levi Right. It may be seen that it took money as well as time to make a home in this new county at that time. But we lived through all and enjoyed our selves nicely. 
In the fall of 1865 October 1 we moved into our house and went on to improve our land as fast as we could by fencing and building I bought timber on Grand River some of it 6 and some 3 miles East of our place to fence and build with. I fenced with nails that I made myself, and hauled them mostly with oxen. I fenced 9 farms with rails and 4 with posts and barb wire.

I improved 13 farms in Iowa the smallest 40 acres 2 of them 160 acres. Three of them were 40 acres each the rest were 80 acres each. I build 10 dwelling houses on our land. Two of them were 30 by $40 \mathrm{ft}$. each they were built on the 160 acre farms. They had good cellars under all with good rock wall. These houses were most substancially built and finished through out. The farm on which I live in Union Co. Iowa has 3 good substantial barns 2 good wagon houses and corn cribs combined and other buildings to the number of 15 good substantial buildings. As I would get my lands inclosed with rails, I would plant hedge inside untill I have made about 7 miles of good Osage hedge fence. Much of the fencing and building material was hauled 10 miles and some of it 13 miles from my timber to the farms. I believe all the hauling of timber, stone and sand to make all of these improvements would average as much as 7 miles. Some sand I hauled 5 miles. Some of the long timbers for barns which were of pine I hauled 30 miles. All the fencing was got out of my native timber which I chopped, split and hauled myself. My boys helped me some I hired very little. I have made 5 cellars all walled with rock. I have made 14 good wells on the land all walled with rock which I quarried and hauled myself. I did all of the walling of these walls and cellars and did most of the digging myself. Beside this improving of land we have done a lot of farming. We have raised thousands of tons of good things to feed and eat: wheat, corn, oats, and other grains, beef, pork, mutton, poultry, vegetables, fruits, honey, butter, eggs, etc. Besides this work I have done a considerable business in the way of entering land and selling it, paying taxes and loaning money sometimes at a profit sometimes a loss. On the whole I have done moderatly well. On the whole I have enjoyed my labor and been happy and believe I have 
done some good in the world. We have had 13 children they are all living this 9th day of March 1900. When I look back over our work that my wife and I have done I wonder how we could have done so much and have done it so well.

Having arrived at the age of 75 years and work becoming so hard and my children having all left us but 2 and they not likely to stay much longer. I concluded to sell our farm and home and stock and tools and go to some small town where we could live comfortably rest from our labors. So we advertised a two day sale on the 17 and 18 days of October 1899. We sold our personal property on the 18 and the farm the 17. The personal property brought about 3200 dollars. The 160 acre farm was bid off by Ed Sherwood but was not taken and was afterward sold to Lew Taylor for eight thousand dollars and we moved March 5, 1900, and we moved to Arispe Union Co., Iowa where we had previously bought a house and lot for $\$ 500$ where with some addition and repairs we have a good home and not much work to do. This 28 day of October 1901.

\title{
A HISTORY OF THE MINERS' BANK OF DUBUQUE, 1836-1845
}

\author{
by Erling A. Erickson
}

Mr. Erickson is in residence at the Harvard Graduate School of Business Administration as the recipient of the Harvard University-Newcomen Society Postdoctoral Fellowship in Business History. This fall he will assume the position of Assistant Professor of History at the University of the Pacific, Stockton, Calif.

As America moved West in the 19th century most pioneer towns were anxious to obtain the services of a bank to aid in economic development. The services of a chartered bank (i.e., one authorized to issue paper money convertible to 
Copyright of Annals of Iowa is the property of State of Iowa, by \& through the State Historical Society of Iowa and its content may not be copied or emailed to multiple sites or posted to a listserv without the copyright holder's express written permission. However, users may print, download, or email articles for individual use. 